\title{
İran Sosyal Bilgiler Ders Kitaplarında Turizm Kavramı
}

\author{
DOI: 10.26466/opus.714104
}

*

\begin{abstract}
Kemal Kaya *
* Doç. Dr., Van YüzüncüYıl Üniversitesi, Eğitim Fakültesi, Van/Türkiye E-Posta: kemalkaya@yyu.edu.tr

ORCID: $\underline{0000-0002-8797-5980}$

\section{Öz}

İran, coğrafi konumu, sahip olduğu tarihi, dini, doğal ve kültürel yapısı itibarıla ileri derecede turizm potansiyeli taşımaktadır. İran, sahip olduğu turistik cazibe merkezleri açısından dünyada 10. strada olmasına rağmen, turizm geliri açısından dünyanın en düşük gelirli ülkeleri arasında yer almaktadır. Bu kısırdöngüyü kırmanın, turizmdeki hizmet sektörünün kalitesinin dünya standartlarına getirilmesinin, turizm kavramının önemini kavratmanın ve bilincini vermenin en etkili yolu eğitimdir. Bunu gerçekleştirmenin yolu ise eğitim ortamının önemli araçlarından olan müfredat ve buna bağlı olarak hazırlanmış ders kitaplarının bu çerçevede hazırlanmış olması ile mümkündür. Bu çalışmada, İran Ĕ̆ itim Bakanlığı tarafından 2018-2019 ĕgitim öğretim yılında yenilenmiş Sosyal Bilgiler Programı ve buna göre yeniden yazılmış olan sosyal bilgiler yedi ve sekizinci sımı ders kitaplarında yer alan turizm olgusunun kavram, görsel ve etkinlik düzeyinde ne kadar işlendiğini ve kullanıldığını belirlemek amaçlanmıştır. Araştırmada nitel araştırma yöntemlerinden doküman analizi tekniği kullanılmıştır. Çalışmada elde edilen bulgulara göre yedinci sımı sosyal bilgiler ders kitabında ağırlıkl olmak üzere her iki sınıfa ait sosyal bilgiler ders kitaplarında turizm kavramı ile ilgili bilgi ve görsellerin yer aldı̆̆ını göstermektedir.
\end{abstract}

Anahtar Kelimeler: Iran, Sosyal Bilgiler, Ders Kitapları, Turizm 
ISSN:2528-9527

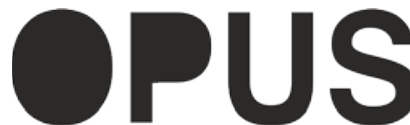

Uluslararası Toplum Araştırmaları Dergisi International Journal of Society Researches
E-ISSN : 2528-9535

Yıl Year: 11

Cilt Volume: 17

Sayı Issue:36

Nisan April 2021

Makalenin Gelis Tarihi Received Date. 03/04/2020 Makalenin Kabul Tarihi Accepted Date. 30/04/2021

\title{
Tourism Concept in Iranian Social Studies Textbooks
}

\begin{abstract}
Iran has an advanced tourism potential in terms of its geographical location, historical, religious, natural and cultural structure. Although Iran ranks 10th in the world in terms of tourist attractions, it is among the lowest income countries in the world in terms of tourism income. Education is the most effective way to break this vicious circle, to bring the quality of the service sector in tourism to world standards, to understand the importance of the concept of tourism and to raise awareness. The way to achieve this is possible with the curriculum which is one of the important tools of the educational environment and the textbooks prepared accordingly. In this study, it is aimed to determine how far the concept of tourism, which is included in the Social Studies Program and the re-written seven and eighth grade social studies textbooks, is processed and used at the concept, visual and activity level. Document analysis technique, one of the qualitative research methods, was used in the research. According to the findings obtained in the study, it shows that the seventh grade social studies textbooks are mostly included in the social studies textbooks belonging to both classes, and information and images related to the concept of tourism.
\end{abstract}

Keywords: Iran, Social Studies, Textbooks, Tourism Concept. 


\section{Giriş}

Coğrafi konumu itibarıyla İran, dört mevsimin aynı anda yaşanabildiği ülkelerden biridir. Sahip olduğu tarihi, dini, doğal ve kültürel yapısı nedeniyle ileri derecede turizm potansiyeli taşımaktadır. İran'ın turizm potansiyeli, turizm kaynaklarına gerekli yatırımların yapılması durumunda dünya turizm pastasından payına düsseni alabilme konusunda son derece uygun özellikler taşımaktadır. 1979 yılında gerçekleşen devrimden sonra sanayi, çeşitli siyasi ve sosyal nedenlerle ihmal edilmiştir. Turizm sektörü de diğer sektörlerdeki gelişmelere kıyasla düşük profilli ticari bir faaliyet olarak kalmıştır. 1979 devriminden sonraki ilk on yılda (1979-1989) doğurganlık ve nüfus artış oranlarında büyük bir artışa yol açan (pronatalist) bir politika benimsenmesi ve aile planlamasının askıya alınması nedeniyle hızlı bir nüfus artışı gerçekleşmiştir. Demografik değişimlere, nüfusun artan hareketliliğine izin veren daha çok ulaşım aracı olarak kullanımı artan özel araba mülkiyeti eşlik etmiştir. Bu gelişmeler İran'ın hem iç hem de dış turizminde artışa neden olmuştur (Mehryar ve Ahmad-Nia, 2004). Günümüz dünyasında turizm endüstrisi gelirleri açısından ana ve en saf endüstri olarak görülse de, mevcut gerçekler dünya ülkelerinin sahip oldukları turizm potansiyelleri ile orantılı bir gelir elde etmediklerini göstermektedir. Başka bir deyişle, dünyadaki turistik konumların dağılımı ile gelirlerinin miktarı arasında anlamlı bir ilişki yoktur. İran, sahip olduğu turistik cazibe merkezleri açısından dünyada 10. sırada olmasına rağmen, turizm geliri açısından dünyanın en düşük gelirli ülkeleri arasında yer almaktadır (Fayzipour ve İmami, 1391).

Bugün dünyada turizm, gelir sağlayan en büyük endüstrilerinden biridir ve hala büyümeye devam etmektedir. Ayrıca yabancı ve kamu yatırımlarının gerçekleştiği önemli bir alan olarak da ön plana çıkmaktadır (Sequeira ve Nunes, 2008). Turizm sektörünün bu özellikleri göz önüne alındığında, uzun vadeli politika hedeflerinden iki tanesi, aynı anda istihdam ve büyüme oranlarında artış ihtimalini barındıran bir potansiyel olarak görülmektedir. Petrol ve gaz endüstrisinin bel kemiğini oluşturduğu İran ekonomisinde turizm gelirleri, ülkenin sahip olduğu turizm potansiyeline nazaran oldukça düşük düzeyde gerçekleşmektedir. İran'da, ülkenin ekonomik yapısal değişimine paralel olarak, en büyük hizmet sektörü olan turizm endüstrisi de gelecek perspektifleri doğrultusunda büyümeye devam etmektedir. Turizm sektörünün 
gelecek vizyonu belgesine göre 2025'te İran, dünyanın en önemli turistik yerlerinden biri olmayı hedeflemektedir. Ülkenin turizm sektöründe 2025 yılı hedefi 20 milyon uluslararası turistin girişi, 36 milyar ABD doları tutarındaki turizm geliri ve 4 milyon istihdam olarak belirlenmiştir. Bu hedeflere ulaşabilmek için bölgesel ekonominin canlandırılması, rekabetçi ve sürdürülebilir bir turizm altyapısının inşasına yoğun çaba sarf edildiği belirtilmektedir. Bunların gerçekleşmesi, insanlar arasında hoşgörü anlayışının gelişmesi, vatandaşlara iş yaratan eğitim programlarının tanıtılması, ülkedeki siyasi istikrarsızlığın kontrol edilmesinde olumlu katkı sağlayacak bir gelişme olarak değerlendirilmektedir (Habibi, Rahmati ve Karimi, 2018).

Tablo 1. Iran'da yıllara göre yurtiçi turizm hareketliliği ve gelecek beklentileri 2012-2022

\begin{tabular}{llllllllll}
\hline & 2012 & 2013 & 2014 & 2015 & 2016 & 2017 & 2020 & 2021 & 2022 \\
\hline $\begin{array}{l}\text { Yurtiçi } \\
\text { turizmi (kişi) }\end{array}$ & $6,915.6$ & $7,163.3$ & $7,434.5$ & $7,726.2$ & $7,978.8$ & $8,266.2$ & $9,245.3$ & $9,618.2$ & $10,017.4$ \\
\hline
\end{tabular}

(Euromonitor International, 2017, s.11-12)

Birinci tabloda 2012-2017 yılları arasındaki yurtiçi gezilerinin nicel verileri ile 2022 yılına kadar bu alandaki beklentilere ilişkin sayılar gösterilmiştir. İran'da yurtiçi seyahatler az da olsa yıllara göre kademeli bir artış göstermiştir. Bu verilerden hareketle İran'da yurtiçi turizm hareketliliğinin önümüzdeki yıllarda da artarak devam edeceği yönünde bir beklenti söz konusudur.

Günümüzde profesyonel bir şekilde icra edilen turizm faaliyetleri büyümeye ve gelişmeye devam etmektedir. Turizm sektörü ülkeler açısından istihdam yaratıcı, döviz getirici ve ekonomik büyümeyi destekleyen bir kaynak olma özelliği taşımaktadır. Bu özelliklerine binaen ülkelerin birbirleriyle rekabet ettiği bir arenaya dönüşmüş durumdadır. Devletler turizm sektörüne büyük yatırımlar yapmakta, tanıtıma önem vererek turistik cazibelerini arttırmaya çalışmaktadırlar. Küresel turizm pastasından daha fazla yararlanabilmek için sektörün altyapısını sağlam temeller üzerine inşa etmeye çaba göstermektedirler. Bütün bunlar turizm eğitiminin ne kadar önemli olduğunu ortaya koymaktadır. Ülkenin sahip olduğu tarihi ve doğal güzellikler hakkında bilgi sahibi olmaya imkân sağlaması, ekonomik boyutlarının farkında olma, turizm altyapısının geliştirilmesindeki katkıları gibi durumlar turizm eğitiminin gerekliliğini ortaya koymaktadır (Samedian, 1388). Diğer ülkelere kıyasla oldukça zayıf ve rekabet gücünden yoksun İran'ın turizm 
potansiyelinin geliştirilmesi için yükseköğretim düzeyinde de turizm eğitiminin verilmesi yönünde öneriler de dile getirilmektedir ( Mehralizadeh, 2017; Kaffashi, 2009). Çünkü eğitim turizm kavramını öğretmenin ve bunun ülke için önemini kavratabilmenin en etkili yolu olarak görülmektedir. Eğitim yoluyla bireylerin edinmesi istenenleri öğrenmesi ve bu yönde bir bilinç sahibi olmaları imkân dâhilindedir. Bu amaçla kurgulanan eğitim ortamının önemli araçlarından birisi ise ders kitaplarıdır. Turizm kavramı ders kitapları materyalinin içeriğinde doğru ve etkili bir tarzda kullanılırsa yeni yetişen nesillerin sektöre karşı daha duyarlı ve bilinçli bir bakış açısı kazanmaları kolaylaşacaktır.

\section{Araştırmanın Önemi}

İran'da ders kitapları eğitim-öğretim sürecinin en önemli ve neredeyse tek kaynağı olma konumunu hala korumaya devam etmektedir. Sosyal bilgiler dersi İran' da ilkokulun ikinci yarısı olan dört, beş ve altıncı sınıflar ile ortaokul düzeyinde okutulmaktadır. İran'da Türkiye'nin eğitim sistemindeki yeniden yapılandırma süreçleri ile aynı dönemlere denk düşecek şekilde eğitim reformları yapılmış, eğitim-öğretim-süreci yapılandırmacılık yaklaşımına uygun olarak yeniden düzenlenmiştir. Yeniden yapılanma çerçevesinde 2016-2017 eğitim-öğretim yılından itibaren ilkokul 6 yıla çıkarılırken 4 yıl olan lise eğitimi ise 3 yıla indirilmiştir. Böylece 12 yıllık eğitim süresi $6+3+3$ şeklinde düzenlenmiştir. 2016-2017 eğitim-öğretim yılından itibaren yeni müfredat uygulamaya konulmuş ve buna uygun olarak yeni yazılmış sosyal bilgiler ders kitapları okutulmaya başlanmıştır. İran'da ders kitapları İran Eğitim Bakanlığı tarafından basılmakta ve tüm okullarda temel kaynak olarak okutulmaktadır.

Literatürde ders kitapları ile ilgili çok farklı konularda yapılmış birçok çalışma bulunmaktadır. Türkiye beşinci sınıf sosyal bilgiler ders kitaplarında turizm kavramını ele alan (İlhan vd, 2015) ile yenilenmiş sosyal bilgiler programı ve ders kitaplarında bunu ele alan (Kaya, 2019)'un çalışmaları zikredilebilir. Diğer konulardaki çalışma sayısının fazlalığının aksine İran sosyal bilgiler ders kitaplarındaki turizm kavramını irdeleyen çalışmaların sayısı nicel olarak azdır. Muhsin (2007) lise coğrafya ders kitaplarında turizm kavramının yerini ele alan araştırmasında, bilişsel düzeyde bile kavramın yeterli düzeyde yer almadığını belirtmektedir. Mohammadian (2010) lise düzeyinde 
okutulan beşeri bilimler ders kitabını turizm kavramı açısından içerik analizine tabi tuttuğu çalışmasında konunun ele alınış biçiminin çoğunlukla turizm ve bileşenlerini yansıtma konusunda yetersiz olarak bulgulamıştır. Diğer bir çalışmasında Mohammadian (2018), sosyal bilgiler ders kitaplarında turizm kavramının İslam perspektifinden uzak, Batılı bir tarzda ele alındığını belirtmektedir. İran açısından turizmin ve diğer bileşenlerin etkileri ve siyasi sonuçlarını göz önüne alarak müfredatı revize etmenin ders kitaplarının da buna göre yeniden yazılması gerektiğini savunmaktadır. Giyani (2008) "198685 yıllarında ilköğretim ders kitapları içeriğinde turizmin kavramının incelenmesi" başlıklı çalışmasında, ilköğretim kitaplarında bahsedilen turizmle ilgili kavramların turizmi temsil etmediği sonucuna varmıştır. Konu ile ilgili diğer bir çalışma ise Mehdipoor Mir vd. (2019)' in "İlkokul altıncı sınıf ders kitaplarının Turizm eğitimi bileşenlerine dayalı içerik analizi" adlı incelemesidir. Çalışma İran ilkokulları altıncı sınıfta okutulan Farsça (okuma), Farsça (yazma), tecrübi bilimler, göksel hediyeler, Kur'an, matematik, sosyalbilgiler, teknoloji, düşünme ve araştırma adlı dokuz ders kitabını turizm kavramı ve bileşenleri açısından içerik analizine tabi tutmuştur. Araştırma, altıncı sınıf ilköğretim ders kitaplarının toplam 829 sayfa olduğunu, turizm ve bileşenine en fazla değininin 60 sayfa ile sosyal bilgiler ders kitabında olduğunu bulgulamıştır. Mohseninia vd. (2014) çalışmada ders kitapları düzeyinde bilişsel eğitimin yanı sıra eğitim ve öğretim ile turizm endüstrisi arasında etkileşim ve anlayış oluşturulması ve turizm eğitimini esas alan kurs ve eğitim amaçlı turistik gezi ve kampların düzenlenmesinin gerekli olduğunu belirtmektedir. Literatüre bakıldığında İran'da ortaokul düzeyinde müfredat ve ders kitaplarında turizm ve bileşenlerine ilişkin herhangi bir çalışmanın tespit edilmediği görülmektedir. Bu nedenle İran ekonomisi açısından büyük öneme sahip olan turizmin gelecek nesillere öğretilmesinin bir yolunun da eğitim olduğu düşünüldügünde bu konuya eğilmenin önemli olduğu düşünülmüştür. Turizm kavramının öğretiminde önemli araçlardan birisi olan İran sosyal bilgiler ders kitapları hakkında bu amaç doğrultusunda bir çalışmanın yapılması gerekli görülmüş̧ür. 


\section{Amaç}

Bu araştırma 2018-2019 eğitim öğretim yılında İran ortaokullarında okutulan sosyal bilgiler ders kitaplarında turizm olgusunun kavram, görsel ve etkinlik düzeyinde ne kadar işlendiğini ve kullanıldığını belirlemek amaçlanmıştır.

\section{Yöntem}

7 ve 8 . sinuf İran sosyal bilgiler ders kitaplarında turizm olgusunun kavram, görsel ve etkinlik düzeyinde ne kadar işlendiğini ve kullanıldığını belirlemek amacıyla yapılan bu çalışmada nitel araştırma yöntemi kullanılmıştır. Nitel araştırma, bireylerin, grupların görüşleri ya da dokümanlar incelenerek elde edilen verilerin yorumlanması durumudur (Creswell, 2013). Patton'un (2014) belirttiği gibi nitel araştırmalar genellikle daha az sayıda kişi ve durum üzerinde derinlemesine ve ayrıntılı bilgi elde etmeyi amaçlayan, araştırmacının kendisinin bir araç olduğu bir araştırma yöntemi olarak tanımlanmaktadır. Bu araştırmada nitel araştırma yöntemlerinden doküman analizi tekniği kullanılmıştır.

\section{Çalışma Materyalleri}

Bu çalışmanın veri kaynağını İran sosyal bilgiler ders kitapları oluşturmaktadır. 2017 yılında İran sosyal bilgiler müfredatı yenilenmiş ve ders kitapları da yeniden yazılmıştır. Yapılandırmacılı̆̆ı esas alan yeni müfredata göre sosyal bilgiler dersi, insan ve çevresinde farklı zamanlarda (şimdi, geçmiş ve gelecek) meydana gelen (siyasi, iktisadi, ictimai, kültürel ve çevresel ) olaylardan bahseden önemli bir ders olarak nitelendirilmektedir. Ağırlıklı olarak tarih, coğrafya, medeniyet, hukuk, insan bilim vb. konularını içermektedir. Türkiye örneğinde olduğu gibi sosyal bilgiler dersi diğer derslerle ilişkilendirilmiştir. Yeni sosyal bilgiler programı çerçevesinde hazırlanan yeni kitaplardan yedinci sınıf sosyal bilgiler ders kitabı beş öğrenme alanı, 12 bölüm ve her biri diğer konularla ilişkilendirilmiş 22 üniteden oluşmaktadır. Sekizinci sınıf sosyal bilgiler ders kitabı ise beş öğrenme alanı, 12 bölüm ve her biri diğer konularla ilişkilendirilmiş 24 üniteden oluşmaktadır. İran eğitim bakanlığının temel amacl; diğer dersler ve programlarında olduğu gibi sosyal bilgiler programı ile de insan fıtratının bir gereği olarak belirtilen islami bir inanç çerçevesinde gençlere kişisel ve sosyal eğitim alanlarını sağlamak için çaba göstermektir. Sosyal bilgiler dersinin amacl; İran'ın ve kültürel kimliğinin etik ve 
dini değerlerini, çıkarlarını kişisel ve sosyal yaşamda koruyan inançlı ve sorumlu bireyler yetiştirmektir. Bu ders yaşam becerileri ile yakından ilişkili bir ders olarak nitelendirilmiştir (İsb, 2018: VIII). Bu kitaplar İran Eğitim Bakanlığınca basılarak ülke genelinde bütün ortaokullarda temel ders materyali olarak kullanılmaktadır.

\section{Verilerin Toplanmast}

Bu çalışmada doküman incelemesine başvurulmuştur. Doküman incelemesi, araştırılması hedeflenen olgu ya da olgular hakkında bilgi içeren yazılı materyallerin analizini kapsar (Yıldırım ve Şimşek, 2016; Ekiz, 2009). Bu kapsamda çalışma materyallerini oluşturan ortaokul yedi ve sekizinci sınıf İran sosyal bilgiler ders kitapları doküman incelemesiyle değerlendirilmiştir.

\section{Verilerin Analizi}

Verilerin çözümlenmesinde içerik analizinden yararlanılmıştır. İçerik analizi "belirli kurallara dayalı kodlamalarla bir metnin bazı sözcüklerinin daha küçük içerik kategorileri ile özetlendiği sistematik, yinelenebilir bir tekniktir" (Büyüköztürk, Çakmak, Akgün, Karadeniz ve Demirel, 2013). İçerik çözümlemesinde araştırmanın temelini oluşturan bir kuram ya da kavramsal çerçevenin olduğu durumlarda, veriler toplanmadan önce bir kod listesi çıkarılabilir. Bu kod listesi hem temalar hem de temalar altında yer alabilecek kavramlar düzeyinde olabilir. Böylece verilerin kodlanması daha kolay olur. Kimi durumlarda da önceden oluşturulan listedeki bazı kodlar işe yaramadıkları için listeden çıkarılabilir (Yıldırım ve Şimşek, 2016). Özellikle analizler için önceden belirlenmiş kategorilerin bir sınırlandırması olmaksızın gerçekleştirilen bir alan çalışması nitel araştırmanın derinliğini, açıklığını ve detaycllığını desteklemektedir (Patton, 2014). Bu çalışmada da İran sosyal bilgiler ders kitaplarının çözümlenmesi için daha önceden belirlenmiş bir kod listesinden yararlanılmıştır. Çalışmada araştırmacı tarafından sosyal bilgiler öğretimi ve ders kitapları konusunda uzman iki akademisyenin görüşleri dikkate alınarak oluşturulan turizm kavramlarını inceleme formu kullanılmıştır. Çalışmanın başlangıcında sosyal bilgiler ders programı incelenmiş, turizm kavramının dersin genel hedeflerinde yer alıp almadığı, varsa belirlenen sınıf düzeylerindeki ders kitaplarında da yer verilip verilmediğine bakılmıştır. 
Çalışmada analiz birimi (ana kategori) olarak kodlama listesindeki turizm konusu alınmıştır. Çözümleme sonucunda kod listesindeki bazı öğelerin doğrudan turizm ile olmadığı görülmüş ve bunlar analize dâhil edilmemiştir. Örneğin tarihi çarşılar turistik bir mekân olmakla birlikte kitap metninde İran Devrimindeki rolü ile ele alındığı için bu analize dâhil edilmemiştir. Ülke tarihleri ve coğrafi özelliklerinin anlatıldığı ünitelerde yer alan ifade ve görseller araştırma bağlamının dışında kaldığı için bunlar da analiz dışında bırakılmıştır. Turizm olgusunun bağımsız bir konu olarak ele alındığı metin ve görseller çalışmamızın esasını oluşturmaktadır.

\section{Geçerlik ve Güvenirlik}

Bu çalışmanın geçerlik ve güvenirliğini sağlamak için şu stratejilere başvurulmuştur: Öncelikle dış güvenirliğin sağlanması için araştırmanın tüm aşamaları (kavramsal çerçevenin nasıl oluşturulduğu, veri toplama, veri analizi, yorumlama) ayrıntılı ve açık bir biçimde verilmiştir. Ders kitapları turizme ilişkin ögeleri içermeleri açısından çözümlenmeden önce alanyazını taranarak bir kod listesi oluşturulmuştur. Kod belirlemenin ardından bunların İran sosyal bilgiler ders kitaplarında yer alıp almadığı, kitaplara göre dağılımları belirlenmeye çalışılmıştır. Böylece analiz süreci, araştırmacının öznel yargı ve değerlendirmeleri dışında gerçekleştirilmeye çalışılmıştır.

Nitel araştırmalarda içerik ya da betimsel analizlerinin güvenirliği kodlama işlemine bağlıdır. Bu nedenle analizin güvenirlik ve nesnelliğinin artması için ilk aşamada kategoriler belirlenmeli ve açık seçik bir biçimde tanımlanmalıdır. Böylece doküman üzerinde diğer araştırmacılar ya da farklı zamanlarda gerçekleştirilecek çözümlemelerde yorumlama farklılıkları önlenebilir. Güvenirliğin test edilmesi için önerilen yöntemlerden biri de "zaman açısından korelasyon"dur. Bu yöntemde aynı dokümanlar araştırmacının kendisi tarafından farklı zaman dilimlerinde incelenir, ardından bu incelemeler arasındaki uyum yüzdesine (percent of agreement) bakılır. Uyum yüzdesinin hesaplanması için "Uzlaşma sayısı/Uzlaşma + Uzlaşmama sayısı” formülünden yararlanılır. Güvenirliliğin kabul edilmesinde uyum yüzdesinin \%70'ten yüksek olması ölçü olarak kabul edilmektedir (Tavşancıl ve Aslan, 2001). Bu çalışmada da güvenirliğin test edilmesi için zamansal korelasyondan yararlanılmıştır. Ders kitapları içerdikleri turizm ile ilgili ögeler açısından araştırmacı tarafından farklı zaman dilimlerinde (ilk çözümleme: 20.09.2019; 
ikinci çözümleme: 11.02.2020) incelenmiş ve iki inceleme arasındaki tutarl1lığa bakılmıştır. Söz konusu formül çerçevesinde uzlaşı düzeyi \% 86 olarak belirlenmiştir. Bu yönden çalışmanın güvenilir olduğu söylenebilir.

\section{Bulgular}

Bu bölümde İran ortaokul yedi ve sekizinci sınıf sosyal bilgiler ders kitaplarının çözümlenmesi sonucunda turizm ile ilgili ögelere ilişkin bulgular tablolar biçiminde sunulmuş, doğrudan alıntılar yapılmış ve bazı görsel öğelere yer verilerek yorumlanmıştır.

İran sosyal bilgiler ders kitapları konu ile ilgili etkinlikler açısından Türkiye'de aşina olduğumuz ders kitaplarından farklı bir tarzda hazırlanmıştır. Etkinlikler bireysel ve toplu etkinlikler olarak iki temel başlık altında değerlendirilebilir. Ünite başında ve anlatı metinleri içinde hem bireysel hem de toplu etkinliklere yer verilmiştir. Sosyal bilgiler ders kitaplarının sonunda bireysel etkinlikler için ayrı bir ek sunulmuştur. Etkinliklerin bu şekilde tasarlanması ve bazı etkinliklerin birden fazla turizm bileşenine yönelik olması nedeniyle tablolarda gösterilmemiştir.

Tablo 2. 7. ve 8. sınf sosyal bilgiler ders kitaplarnda turizm ve bileşenleri ile ilgili ifade ve görseller

\begin{tabular}{lllll}
\hline \multirow{2}{*}{ Sinif } & 7 & & 8 & \\
\cline { 2 - 5 } & İfade & Görsel & İfade & Görsel \\
\hline Turizm & 24 & & 11 & - \\
\hline Turist & 9 & & 5 & - \\
\hline Turizm Hizmetleri & 13 & 7 & 2 & - \\
\hline
\end{tabular}

İran sosyal bilgiler yedinci sınıf ders kitabında turizm ve bileşenlerine kırk altı yerde değinilmiş ve bunlarla ilgili olarak yedi adet görsele yer verilmiştir. Kitapta en çok tekrarlanan kavramın turizm olduğu görülmektedir.

Sosyal bilgiler yedinci sınıf ders kitabındaki sekizinci bölüm "İran'da Turizm" başlığı taşımaktadır. Bu bölümle bağlantılı olarak 15. ünite "Turizm Nedir" ve 16. ünite ise "İran'ın Turistik Yerleri" adlarını taşımaktadır. Yedinci sinıf sosyal bilgiler ders kitabının anlatı metninde turizm olgusu ve bileşenlerinin bütün boyutları ele alındığı görülmektedir. Ünitenin giriş kısmında İran'ın sahip olduğu turizm potansiyeline vurgu yapılarak dünya s1ralamasında sahip olduğu doğal güzellikler açısından beşinci, tarihi ve kül- 
türel eserler açısından ise onuncu sırada yer aldığı belirtilmiştir. Turizm, turizm türleri ve turizm hizmetleri hakkında bilgi verilerek İran açısından önemine değinilmiştir. Turistik bir geziyi planlamayı esas alan bir etkinlik örneği ile öğrencinin konuya ilgisinin arttırılması hedeflenmiştir. Ayrıca öğrencilerin turistik gezilere ilgisini arttırmak amaciyla Kuran'daki Rum suresinin “ Ey Peygamber, insanlara yeryüzünü gezmelerini ve kendilerinden öncekilere ne olduğunu görmelerini söyle" emrini belirten 42. ayetine yer verilmiştir (İsb 7, s.89-90).

Sosyal bilgiler yedinci sınıf ders kitabında turizm ile ilgili etkinlik örnekleri de sunulmuştur. "Birkaç arkadaşınıla beraber üç-dört günlüğüne bir turizm şirketi tarafindan İran'da bir yere götürüleceğinizi planlayın. Fakat seyahat edilecek yerin seçimini sizler yapmalısını. Grup olarak seyahat edilecek yeri hangi özellikleri nedeniyle seçtiğinizi kâğıda yazarak simfta okuyunuz" (İsb 7, s.90), "Bugüne kadar herhangi bir seyahat tecrübeniz oldu mu? Sinıfta anlatınz" (İsb 7, s.91) ve "Seyahati gerektiren sebepler neler olabilir ve turizmin gerekliliğini tartışını" (İsb 7, s.91) gibi etkinliklerle konu hakkında öğrencilerin katılımı sağlanmaya çalışılmıştir.

Sosyal bilgiler sekizinci sınıf ders kitabında turizm ve bileşenlerine on sekiz yerde değinilmiş ama bunlarla ilgili olarak her hangi bir görsele yer verilmemiştir. Sekizinci sınıfa ait sosyal bilgiler ders kitabında da en çok turizm kavramına değinildiği görülmektedir.

Her iki ders kitabı karşılaştırıldığında, birinci tabloda yer alan kavramlara dair ifade ve görsellere sekizinci sınıf sosyal bilgiler ders kitabına nazaran yedinci sınıfa ait ders kitabında daha çok yer verildiği görülmektedir. Yedinci sınıf sosyal bilgiler ders kitabında "Turizm Nedir" adlı bir ünitenin olması ve konunun detaylı bir şekilde ele alınmasından kaynaklı olduğu ifade edilebilir. Ayrıca sosyal bilgiler yedinci sınıf ders kitabı İran tarih ve coğrafyasına ait konuları içerirken sekizinci sınıfa ait sosyal bilgiler ders kitabı ise dünya tarihi ve coğrafyasına ait konulara yer verilmiştir. Turizm kavramına ait temel bilgiler yedinci sınıf ders kitabında verildiği için sekizinci sınıf ders kitabının da bunu referans alması nedeniyle daha az ifade ve görsel içerdiği söylenebilir. Turizm ile ilgili olarak aşağıdaki görsellerden üç tanesine yer verilmiştir. 

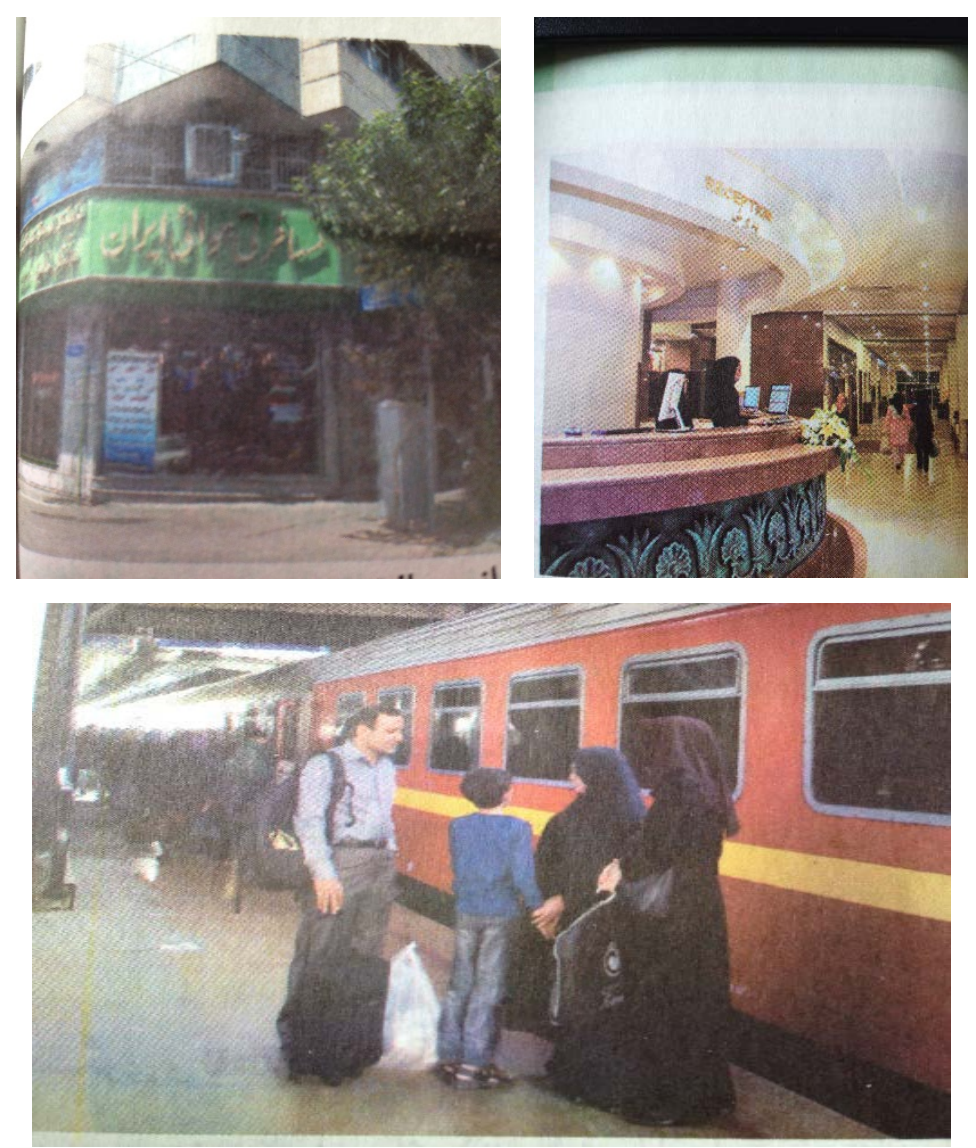

İlk sırada bir turizm acentesine ait görsele (İsb 7, s.90). yer verilirken ikincisinde turizm hizmetlerinin önemli bir bileşeni olan konaklama faaliyetinin sağlayıcısı olan bir otele ait resepsiyon fotoğrafı verilmiştir. Üçüncü sırada ise yine turizm faaliyetlerinin önemli bir boyutu olan ulaşım hizmetlerine ait bir görsele yer verilmiştir (İsb 7, s.91).

Tablo 3. Sosyal bilgiler 7. ve 8. sınf ders kitaplarnda doğal güzellikler ile ilgili ifade ve görsellere yer verilme durumu

\begin{tabular}{lllll}
\hline \multirow{2}{*}{ Sinıf } & 7 & & 8 & \\
\cline { 2 - 5 } & İfade & Görsel & İfade & Görsel \\
\hline Doğal Güzellikler & 34 & 11 & 18 & 12 \\
\hline
\end{tabular}


Sosyal bilgiler yedinci sınıf ders kitabında turistik amaçlı ziyaret edilen doğal güzelliklere otuz dört defa değinilmiş ve bunlardan on bir adet görsele yer verilmiştir. Kitapta “Ülkemiz İran eşsiz doğal güzelliklere sahiptir. Bitki ve hayvan sayısı ve çeşitliliği açısından Irran'ın dünyada eşine ender rastlanan bir ülke olduğunu biliyor musunuz?" (İsb 7, s.57) cümleleri ile İran'ın sahip olduğu doğal güzellikler vurgulanmıştır.

Sosyal bilgiler sekizinci sınıf ders kitabında ise doğal güzelliklere on sekiz defa değinilmiş ve bunlardan on iki adet görsele yer verilmiştir. Avustralya kitasinı konu olarak ele alan anlatı metninde "Avustralya ve Yeni Zelanda, uzun sahilleri, farkh yerleri ve hayvan çeşitleri ile sahip olduğu doğal güzellikleri ile turistler için oldukça çekicidir" ifadesine yer verilmiştir.

İran'ın doğal güzellikler açısından sahip olduğu turizm potansiyeli oldukça zengin olup dünya sıralaması açısından ilk beş arasında yer almaktadır (Morakabati, 2011; Baum ve O'Gorman, 2010; İsb 7, s.89-90). Bu potansiyelin özellikle içerik açısından İran odaklı olarak hazırlanmış olan yedinci sınıf sosyal bilgiler ders kitabına sayısal olarak daha çok yansıtıldığı görülmektedir. İran'ın sahip olduğu doğal güzellikler ve bunlara ait tanıtıcı bilgilere yer verilmiştir. Doğal güzellikler ile ilgili olarak aşağıdaki görseller örnek olarak sunulmuştur.

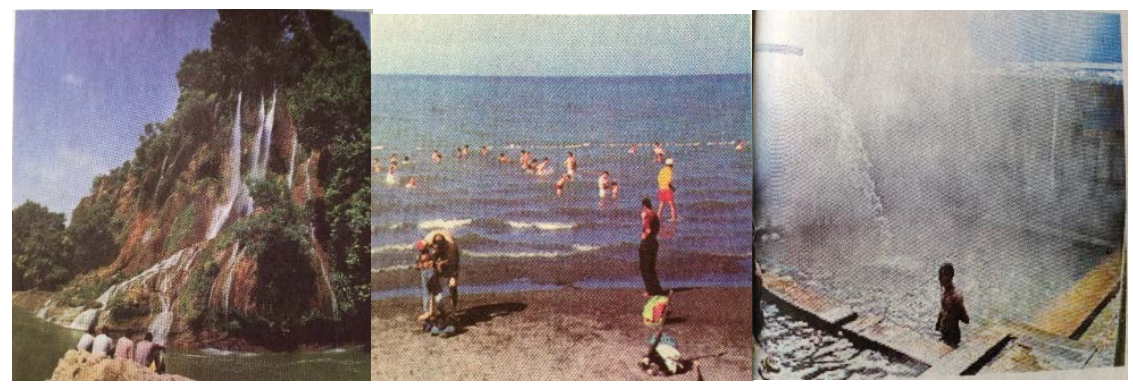

Birinci sırada yer alan görsel Luristan'da bulunan bir şelaleye, ikinci sıradaki ise Hazar Denizi kıyılarındaki bir sahile aittir (İsb 7, s.99). Üçüncü görsel Erdebil'deki bir kaplıcanın fotoğrafıdır (İsb 7, s.100).

Tablo 4. Sosyal bilgiler 7. ve 8. sinff ders kitaplarnda tarihi eserlere dair ifade ve görsellere yer verilme durumu

\begin{tabular}{lllll}
\hline \multirow{2}{*}{ Sinff } & 7 & & 8 & \\
\cline { 2 - 5 } & İfade & Görsel & İfade & Görsel \\
\hline Tarihi Eserler & 53 & 67 & 3 & 4 \\
\hline
\end{tabular}


Sosyal bilgiler yedinci sınıf ders kitabında tarihi eserlere elli üç defa değinide bulunulmuştur. Yine bu değinilere paralel olarak altmış yedi adet görsele de yer verilmiştir. Tarihi eserlere bu kadar fazla yer verilmesinin nedeni İran coğrafyasının tarihsel süreci ile ilgili olarak anlamlıdır. Kitapta "Geçmişten günümüze kalan birçok tarihi eser Irran'da çok eskilere dayanan bir insanlık tarihinin varlığına işaret etmektedir" (İsb 7, s.102) cümlesi ile tarihi eserlere değinilmiştir.

Yerleşik hayat, hayvanların evcilleştirilmesi ve tarımsal faaliyetlerin 10 000 yıl öncesine kadar dayandığı İran'da tarihi süreç içerisinde birçok medeniyetler kurulmuştur. MÖ 3. binyılda Güneybatı İran'da ve Güney Mezopotamya'da Elam uygarlığı ve ardından başlayan Med dönemi, İran'ın dünya tarihinde öne geçmesine neden olmuştur. Medlerden sonra gelen ve onlarla etnolojik ve kültürel açıdan akraba olan Ahameniş Hanedanı'nın kurmuş olduğu Pers İmparatorluğu, Ege Denizi'ne kadar olan alanda uzun süre hükümranlığını sürdürmüştür. Makedonya Kralı İskender'in kısa süreli hâkimiyetinden sonra Seleukoslar İran'da hâkimiyet kurmuşlardır. Ardından 500 yıl sürecek olan Partlar dönemi başlamıştır. Erdeşir' in Partlara son vererek kurmuş olduğu Sasani İmparatorluğu da İran'da 400 yıllık bir hâkimiyet sürdürmüştür (Naskali, 2000). Farklı medeniyetlere ev sahipliği yapmış olan İran'da doğal olarak tarih boyunca farklı dinler, diller ve kültürler varlık göstermişlerdir. İran tarihinin farklı dönem ve kültürlerinden günümüze kadar ulaşmış olanların dünya kültür ve mirası açısından oldukça önem arz ettiği bilinmektedir.

Sosyal bilgiler sekizinci sınıf ders kitabında tarihi eserlere üç adet değini ile dört adet görsele yer verilmiştir. Kitapta "Geçmişten günümüze kalan tarihi eserler Afrika'nın en önemli turistik mekânlarındandır" (İsb 8, s.148) cümlesi ile tarihi eserlere değinide bulunulmuştur.

Tabloda da görüldüğü gibi turistik açıdan önemi olan tarihi yerlere ilişkin vurgular, yedinci sınıf sosyal bilgiler ders kitabında daha fazladır. İki ders kitabındaki ifadeler arasındaki miktarın farklılı̆̆ının nedeni; yedinci sınıf sosyal bilgiler ders kitabı çoğunlukla İran tarih ve coğrafyası ile ilgili konuları içerirken sekizinci sınıfa ait ders kitabı ise diğer ülkelerin tarih ve coğrafyasına ilişkin bilgileri içermesindendir. Tarihi mekânlar ile ilgili olarak üç görsel örnek olarak sunulmuştur. 


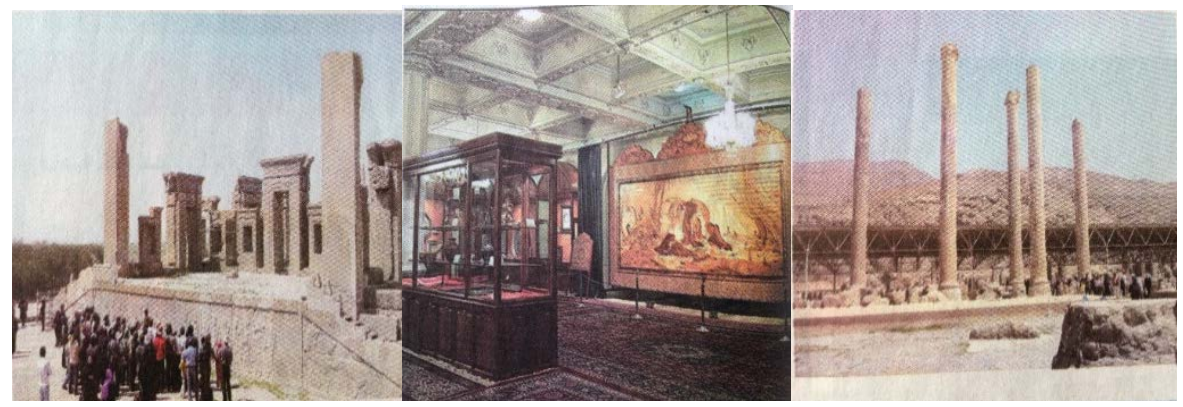

Yukarıda belirtildiği gibi tarih boyunca farklı medeniyetlere ev sahipliği yapmış olan İran sahip olduğu tarihi eser zenginliği açısından dünyada ilk sıralarda yer almaktadır. Ders kitabında İran'ın sahip olduğu bu tarihi eserler ve bunların sergilendiği bir müzeye ait görsellere yer verilmiştir (İsb 7, 97-98).

Tablo 5. Sosyal bilgiler 7. ve 8. sinı ders kitaplarnda kültür ve sanat eserlerine dair ifade ve görsellere yer verilme durumu

\begin{tabular}{lllll}
\hline Sinif & 7 & & 8 & \\
\cline { 2 - 5 } & İfade & Görsel & İfade & Görsel \\
\hline $\begin{array}{l}\text { Kültür ve } \\
\text { Sanat Eserleri }\end{array}$ & 27 & 28 & 5 & 8 \\
\hline
\end{tabular}

İran sosyal bilgiler yedinci sınıf ders kitabında turizm bileşeni olan kültür ve sanat eserlerine yirmi yedi defa değinide bulunulmuştur. Ayrıca konu ile ilgili yirmi sekiz görsele yer verilerek bilişsel düzeyde pekiştirme yoluna gidilmiştir. Kitapta kültür ve sanat ile ilgili" Nevruz İran'ın dünyaya kültürel bir hediyesidir" İsb 7, s.149 ve "Geçmiş asırlarda sanatkârlar kalaycllk, kuyumculuk, dericilik, musıkî... ve nakışçllk gibi alanlarda birçok zarif ve güzel sanat eserleri meydana getirdiler" (İsb 7, s.152) cümlelerine yer verilmiştir.

Sosyal bilgiler sekizinci sınıf ders kitabında kültür ve sanat eserleri beş değini ve sekiz adet görsel ile yer almıştır. Kitapta "Hoca Reşidüddin Fazlullah Hemedanî Moğol döneminin meşhur olan İranlı siyaset adamlarnndan biri olup kültür ve sanatın gelişimine ön ayak oldu" (İsb 8, s.99) cümlesine yer verilmiştir.

Gerek İslam öncesi gerekse İslam sonrası dönemde İran'da hüküm sürmüş olan devletlerden günümüze kadar birçok sanat eseri ulaşabilmiştir. İslâm öncesi dönemde güçlü bir sanat çevresinin bulunduğu İran'da sanat, İslâmî dönemde yeni tanışılan kültürlerden aldığı unsurlarla nevi şahsına mahsus bir hüviyet kazanmıştır. İki sınıfa ait ders kitapları karşılaştırıld1ğında; İran kültür ve sanatına ilişkin ifadelere sosyal bilgiler yedinci sınıf ders 
kitabında daha fazla yer verildiği bulgulanmıştır. Yukarıda da ifade edildiği gibi sosyal bilgiler yedinci sınıf ders kitabının İran merkezli konuları içermesi nedeniyle İran kültür ve sanatına ilişkin ifade ve görsellere daha fazla yer vermiştir. Kültür ve sanat eserleri ile ilgili olarak aşağıdaki görsellerden üç tanesine yer verilmiştir.
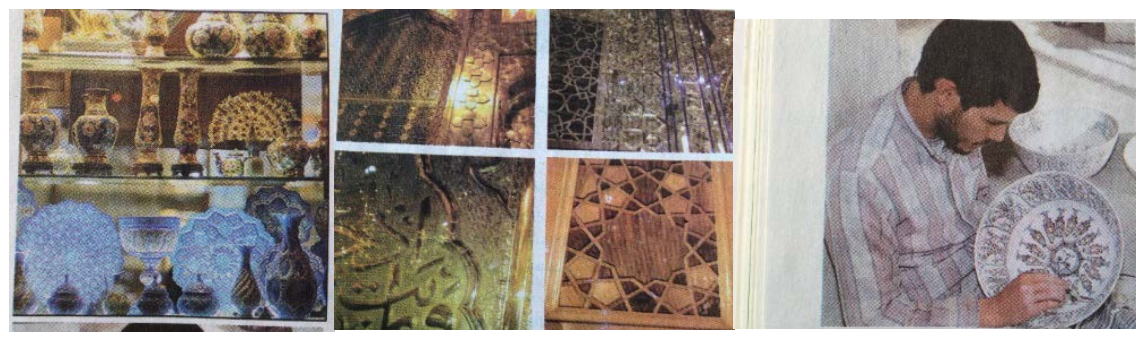

Yukarıdaki görsellerde mimari, cam, seramik, çini, ahşap vb. alanlarda üretilmiş sanat ürünlerine ait resimlere yedi ve sekizinci sinıf sosyal bilgiler ders kitaplarında yer verilmiştir.

Tablo 6. Sosyal bilgiler 7. ve 8. sinff ders kitaplarnnda kutsal mekânlara dair ifade ve görsellere yer verilme durumu

\begin{tabular}{lllll}
\hline \multirow{2}{*}{ Sinuf } & 7 & & 8 & \\
\cline { 2 - 5 } & İfade & Görsel & İfade & Görsel \\
\hline Kutsal Mekânlar & 11 & 7 & 2 & 2 \\
\hline
\end{tabular}

Sosyal bilgiler yedinci sınıf ders kitabında İran'ın önemli turistik merkezlerinden olan kutsal mekânlara on bir defa değinilmiştir. Bu mekânlara ilişkin olarak yedi adet görsele yer verilmiştir. Kitapta kutsal mekânların turistik boyutu "Her yıl çok sayıda Iranlı ve yabancı turist İmam Rıza türbesini ziyaret etmek amacıyla Meşhed'e gelmektedir" (İsb 7, s.94) cümlesi ile ifade edilmiştir.

Sosyal bilgiler sekizinci sınıf ders kitabında kutsal mekânlarla ilgili olarak iki ifade ve görsele yer verilmiştir.

Dünyadaki turizm faaliyetlerinin genel niteliği ile karşılaştırıldığında İran'daki turizm faaliyetlerinin bu açıdan farklılaştığı görülmektedir. Turizm verilerine göre 1979 devriminden sonra yurt dışından İran'a gelen turistlerin büyük çoğunluğunun dini amaçlarla geldiğini göstermektedir. İran'da Meşhetteki İmam Rıza Türbesi, Kumdaki Fatıma Türbesi ve Şirazdaki Şah-1 Çerağ Türbeleri gibi birçok kutsal mekânlar, başta Irak olmak üzere Azerbaycan, Filistin, Bahreyn, Suudi Arabistan, Pakistan ile Afganistan gibi Şiilerin 
yoğun olduğu bölgelerden ve dünyanın birçok yerinden gelen milyonlarca Şii Müslümanın ziyaretine mazhar olmaktadır (Seyfi ve Hall, 2019). Şia düşüncesi açısından türbe ziyaretleri mânevî destek kazanma, rahmet ve şefaate nâil olmanın yanında imamlarla ve onların ortaya koyduğu İslâm vizyonuyla bağları kuvvetlendirme aracı olarak işlev görmektedir. Bunu, ziyaretler sırasında okunması gereken duaları içeren kitapçıklarda da görmek mümkündür. "Ziyaretnâme" adı verilen bu dualarda imamların belirli erdemleri sayılır ve onlara olan bağllık ifade edilir. Ziyaretler, imamların "imamzâde" olarak bilinen ahfadını da kapsyacak tarzda olabilmektedir. Muhtemelen uzak beldelerdeki imamların türbelerine seyahat edemeyenler için türetilmiş olan bu ziyaretlerde de imamzâdelerin erdemlerinden bahsedilip dualar okunur ve onlardan şefaat dilenir. İran'da 1000'den fazla imam zade türbesi bulunmaktadır (Algar, 2000). Şii turistlerden elde edilen turizm gelirleri, İslam devriminden bu yana İran devleti için en önemli kaynaklar arasında yer almıştır. 1.6 milyar Müslümanın olduğu günümüz dünyasında yaklaşık 200 milyon Şii nüfus mevcut olup bunun neredeyse yarısına yakın bir miktarı olan 70-75 milyonu İran'da yaşamaktadır. Yedinci sınıf sosyal bilgiler ders kitabında bu konu ifade, görsel ve etkinliklere yer verilerek işlenmiştir. Kutsal mekân turizmi ile ilgili olarak kitapta yer alan görsellerden üç örnek aşağıda verilmiştir.
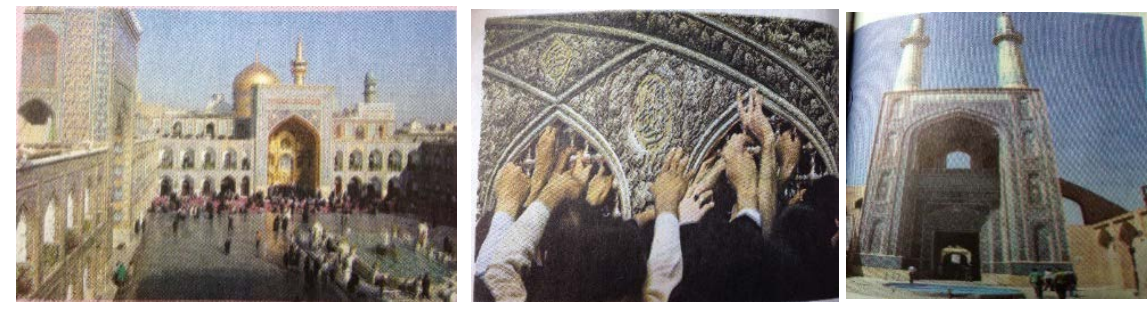

İlk sırada Şii inancına göre sekizinci imam olan Musa Kazım Camii ve Türbesinden bir görüntüye, İkinci sırada ise kutsal bir mekânı ziyaret edenlerin dua ile yakarışlarına dair bir görüntüye yer verilmiştir (İsb 7, s.95). Üçüncü sırada Yezd Camiine ait bir resim verilmiştir (İsb 7, s.94).

Tablo 7. Sosyal bilgiler 7. ve 8. sinf ders kitaplarnda turizmin ekonomik boyutuna dair ifade ve görsellere yer verilme durumu

\begin{tabular}{lllll}
\hline \multirow{2}{*}{ Sinuf } & 7 & & 8 & \\
\cline { 2 - 5 } & İfade & Görsel & İfade & Görsel \\
\hline Ekonomi & - & - & 2 & 3 \\
\hline
\end{tabular}


Turizm ve bileşenlerine ilişkin en çok değininin olduğu sosyal bilgiler yedinci sınıf ders kitabında turizmin ekonomik boyutuna hiç değinilmemiştir. Turizmin ekonomik boyutu sosyal bilgiler sekizinci sınıf ders kitabında iki değini ve 3 adet görsel ile işlenmiştir.

Turizm olgusunun toplumsal alana doğrudan yansiyan en önemli boyutu ekonomik açıdan iyileşmedir. Sosyal bilgiler yedinci sınıf ders kitabında "İran'da Turizm" adlı sekizinci bölümde turizm kavramı detaylı bir şekilde ele alındığını yukarıda ifade etmiştik. Turizmin ülkelerin ekonomik açıdan gelişmelerine olan katkısına ilişkin doğrudan ifade ve görsellere sekizinci sınuf sosyal bilgiler ders kitabında yer verilmiştir. Turizm gelirlerinin ülke ekonomilerine olan katkısı örneği olarak Türkiye ve Birleşik Arap Emirlikleri örnekleri verilmiştir. Ders kitabında "Türkiye ve Birleşik Arap Emirlikleri gibi bazı ülkeler turizm faaliyetleri sayesinde gelirlerini çeşitlendirerek ekonomilerini geliştirmişlerdir" (İsb 8, s.126) ifadesiyle her iki ülke açısından turizmin ekonomik katkısına işaret edilmiştir.

İran turizm politikalarının belirlenmesi ile buna ilişkin gelecek perspektiflerinin belirlenmesinde genellikle Türkiye, Mısır ve Birleşik Arap Emirlikleri rol modeli olarak almakta ve bunlarla bir kıyaslamaya girişmektedir. Sahip olduğu doğal ve tarihi güzelliklerin potansiyel olarak bu ülkelerden daha fazla olmasından kaynaklı gelirlerin de buna paralel olması gibi beklenti oluşmaktadır (Seyfi ve Hall: 2019; Fayzipour ve İmami, 1391; Morakabati, 2011; Baum ve O'Gorman, 2010; Samedian vd, 1388; Shakoori vd, 2014; Habibi vd. 2018).

Turizmin ekonomik gelişme açısından gelecek nesillere önemini kavratmak amaciyla sosyal bilgiler öğretiminde buna yer verilmesi bir gereklilik olarak ortaya çıkmaktadır. Sosyal bilgiler sekizinci sınıf ders kitabında turizmin ekonomik boyutuna ilişkin yer verilen görsel unsurlardan üç tanesi burada örnek olarak sunulmuştur.
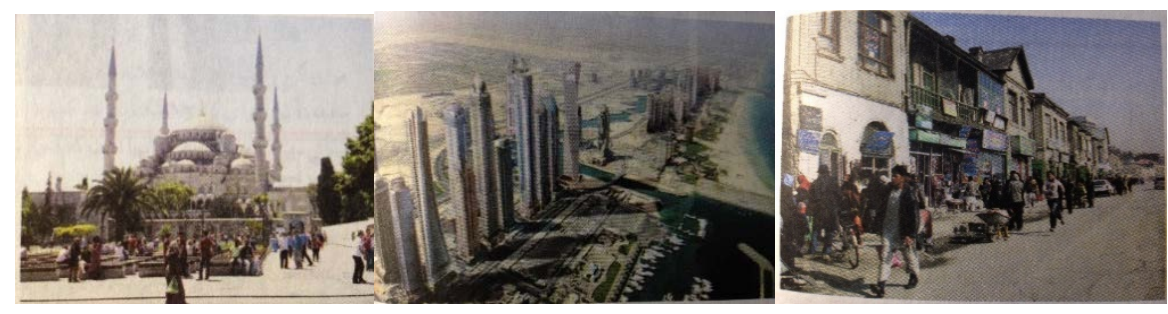
İlk sıradaki görselde turizm gelirlerinin ekonomik gelişimine katkı sağlayan ülkelerden bir olarak belirtilen Türkiye' de turistlerin en çok ziyaret ettiği mekânlardan biri olan Sultanahmet Camiine ait bir resim verilmiştir. İkinci görsel ise Türkiye ile birlikte zikredilen Birleşik Arap Emirlikleri'ne ait bir resim yer almaktadır. Üçüncü görselde, dış müdahale ve iç çatışmaların sebep olduğu güvenlik sorunları nedeniyle Irak ve Afganistan gibi ülkelerin ekonomik açıdan geri kaldığı belirtilmiş ve bu durum Afganistan'a ait bir resimle vurgulanmak istemiştir (İsb 8, s.126).

Tablo 8. Sosyal bilgiler 7. ve 8. sinf ders kitaplarnda bilimsel amaçl turizme dair ifade ve görsellere yer verilme durumu

\begin{tabular}{lllll}
\hline Sinıf & 7 & & 8 & \\
\cline { 2 - 5 } & İfade & Görsel & İfade & Görsel \\
\hline Bilimsel & 1 & - & - & - \\
\hline
\end{tabular}

Bilimsel amaçlı turizm hareketliliğine ilişkin olarak sosyal bilgiler yedinci sınıf ders kitabında sadece bir kez değini yapıldığı görülmektedir. Konu ile ilgili olarak herhangi bir görsele yer verilmemiştir. Sekizinci sınıfa ait ders kitabında ise bir değini ve görsel tespit edilmemiştir.

Gelişmiş ülkelerin çoğunda spor, kongre ve fuar organizasyonları çok sayıda insan hareketliliğine imkân verdiği için önemli miktarda turizm geliri elde etmeyi mümkün kılmaktadır. İran sosyal bilgiler yedinci sınıf ders kitabında turizm türlerini tanıtan anlatı metninde bilimsel amaçlı turizm faaliyeti ile ilgili olarak "Bazı insanlar bilimsel faaliyetler veya fuarlar... için seyahat ederler..." (İsb 7, s.90) ifadesi kullanılmıştır.

\section{Sonuç ve Tartışma}

Dünya ve İran ekonomisi açısından önemli gelir kaynaklarından biri olan turizm sektörü kavram olarak hem İran sosyal bilgiler dersinin genel amaçlarında hem de öğretim programında yer almaktadır. Çalışma neticesinde elde edilen bulgular, turizm kavramının İran sosyal bilgiler ders kitaplarında s1nıflar düzeyinde farklılık arz edecek şekilde yer aldığını göstermektedir. Sosyal bilgiler programının yapısı, kitapların içerdiği konuların türü ve öğrencilerin gelişim düzeylerinin bu farklılaşmaya yol açtığı söylenebilir. Farklılaşmaya ilişkin elde edilen bu bulgu, Türkiye'deki sosyal bilgiler ders kitaplarında turizm kavramını ele alan (İlhan vd, 2015) ve (Kaya, 2019)'nın çalısma sonuçları ile örtüşmektedir. Her iki çalışmada da Türkiye'deki sosyal bilgiler 
ders kitaplarında yer alan turizm kavramlarının kitapların içerdiği konuların türü, öğrencilerin gelişim düzeyleri ve sınıf bağlamında farklılaştığı bulgulanmıştır. Aynı şekilde İran sosyal bilgiler ders kitaplarının da Türkiye örneğinde olduğu gibi sınıf düzeyleri, kitapların içerdiği konuların türü bağlamında farklılaştığı bulgulanmıştır. Öğrencilerin öğrenme düzeyleri, kavramların özelliklerine ve öğrenme süreçlerine bağlı olarak değişebilmektedir. $\mathrm{Bu}$ nedenle sosyal bilgiler programında hangi kavramların ne düzeyde öğretilmesi gerektiği konusunda bir çerçeve ortaya konulmaktadır. Buna göre kavramların ders kitaplarında yer alması ve öğretilmesi konusunda giriş, geliştirme ve pekiştirme olmak üzere üç aşama belirlenmiştir. Soyut nitelikler taşıyan kavramların yukarıda belirtilen kategoriler uyarınca öğretilmesi, öğrencilerin bu kavramları bir süreç çerçevesinde soyutluktan somutlamaya ve disiplinler arası bir yaklaşımla diğer boyutlarını da öğrenerek genelleme yapabilmesine imkân verecektir (Barth-Demirtaş 1997, s.10.12). Turizm kavramının da bu sınıflama çerçevesinde taşıdığı özellikler nedeniyle İran sosyal bilgiler ders kitaplarında yer alma durumunun sınıf düzeylerine göre farkl1laşmasının bir nedeni olarak değerlendirilebilir.

Her iki sınıfa ait ders kitapları karşılaştırıldığında; sosyal bilgiler sekizinci sınıf ders kitabına nazaran yedinci sınıfa ait ders kitabında turizm kavramına ilişkin ifade ve görsellere daha fazla yer verildiği tespit edilmiştir. Bunun nedeni yedinci sınıf sosyal bilgiler ders kitabında "Turizm Nedir" adlı bir ünitenin olması ve konunun detaylı bir şekilde ele alınmasından kaynaklı bir durum olarak değerlendirilebilir. Diğer bir neden ise yedinci sınıf sosyal bilgiler ders kitabı İran tarih ve coğrafyasına ait konuları içerirken sekizinci sınıfa ait ders kitabının dünya tarihi ve coğrafyasına ait konulara yer vermesidir. İki ders kitabı arasında turizm kavramına yer verme açısından farklılaşmanın eğitim-öğretim süreçlerinde sıklıkla başvurulan yakından uzağa ilkesiyle uyumluluk arz ettiği ifade edilebilir.

Çalışmada elde edilen bulgulardan biri de İran'daki turizm faaliyetlerinin dünyanın birçok yerinden farklı bir türde yoğunlaştı̆̆ını göstermektedir. Şii kültüründe kutsal mekânların ziyaret edilmesinin dini bir vecibe olarak değerlendirilmesi geçmişten gelen bir uygulama olarak devam etmektedir. Bütün turizm faaliyetleri içerisinde kutsal mekânların ziyaret edilmesi ile gerçekleşen hareketliliğe ilişkin sayısal veriler de bunu doğrulamaktadır. 2017 verilerine göre (ICHTO 2017) İran'da turizm hareketliliğine katılan 4,911,920 turistin 2,223,648'sının Meshed ve Kum gibi kutsal mekân ziyaretçisi olması 
ve bunun ders kitaplarında da ayrıca vurgulanması önemli bir husus olarak değerlendirilebilir.

İlhan ve arkadaşları (2015) yaptıkları çalışmada Türkiye sosyal bilgiler ders kitaplarında turizm kavramının yaz turizmi ağırlıklı olmak üzere ele alındığını belirtmişlerdir. İran sosyal bilgiler ders kitaplarında ise turizm kavramının daha farklı boyutları ile ele alındığı görülmektedir. İran sosyal bilgiler ders kitaplarına ilişkin elde edilen bu bulgular, Kaya (2019)'nın yenilenmiş sosyal bilgiler ders programı ve kitapları hakkındaki çalışmada elde ettiği verilerle örtüşmektedir.

Sosyal bilgiler yedinci sınıf ders kitabındaki “İran'da Turizm” ile "İran'ın Turistik Yerleri" konu başlıkları altında turizm ile ilgili detaylı bilgi ve görsellere yer verilmiştir. Bu başlıklar altında verilen bilgiler öğrencilerde turizm bilincinin gelişmesi açısından önemlidir. Özellikle sosyal bilgiler yedinci sınıf ders kitabında turizm olgusunun öğrenciler tarafından daha net anlaşılmasını kolaylaştıracak şekilde birçok ünite içerisinde bağlantılar kurulmuştur. Böylece turizmin farklı boyutları ile anlaşılmasını sağlayacak bir zemin sunulmuş olmaktadır.

İran'da ilkokul ve lise düzeyindeki program ve ders kitapları üzerine yapılmış çalışmalara bakıldığında 2016-2017 eğitim-öğretim yılından itibaren yenilen müfredat ve buna uygun olarak yeni yazılmış sosyal bilgiler ders kitaplarında turizm kavramına yer verme konusunda bir iyileşme olduğu bulgulanmıştır. İlkokul altıncı sınıf sosyal bilgiler ders kitabında turist kelimesine yalnızca bir kez değinilmiş iken (Mahdipoor Mir vd., 2019) çalışma materyalimiz olan yedinci sinif sosyal bilgiler ders kitabında dokuz, sekizinci s1nıf ders kitabında ise beş kez olmak üzere toplam on dört defa vurgulanmıştır. Mahdipoor Mir vd. (2019) çalışmalarında ilkokul altıncı sınıf sosyal bilgiler ders kitabında turizm kavramına altmış defa değinildiğini verildiğini bulgulamışlardır. Çalışma materyalimiz olan yedinci sınıf sosyal bilgiler ders kitabında turizm kavramı ve bileşenlerine iki yüz seksen sekiz, sekizinci sınıf ders kitabında ise yetmiş yedi kez olmak üzere toplam üç yüz altmış beş defa değinilmiştir. Ders kitaplarında turizm kavramına yapılan değinilerdeki bu sayısal artış, Giyani (2008), Mohammadian (2010), Mohseninia vd. (2014), Mohammadian (2018) ve Mehdipoor Mir vd. (2019) tarafından daha önce yapılmış olan çalışmalarda vurguladıkları ve önerdikleri hususların dikkate alındığı anlamına gelmektedir. Çalışma materyalimiz olan ve yenilenen müf- 
redat çerçevesinde yazılmış olan ortaokul sosyal bilgiler ders kitaplarında turizme ilişkin kavramlara gösterilen dikkat düzeyinin sadece bilişsel düzeyde kalmaması adına turizme ilişkin değer ve kavramların kurumsallaştırılması için daha duygusal ve işlevsel boyutların da dikkate alındığı görülmektedir. Özellikle yedinci sınıf ders kitabında kavram ile ilgili farklı etkinliklerin planlanmış olması önem arz etmektedir.

Bilindiği gibi turizm ve bileşenlerinin toplumsal alana doğrudan yansıyan en önemli boyutu ekonomik açıdan iyileşmedir. İran açısından büyük bir gelir potansiyeli olmasına rağmen ortaokul sosyal bilgiler ders kitaplarında en az vurgulanan konunun ekonomik boyut olduğu görülmektedir. Bu bulgu, Mehdipoor Mir vd. (2019)'un ilkokul altıncı sınıf sosyal bilgiler ders kitabı incelemesinde elde ettiği sonuçlar ile de örtüşmektedir.

İncelenen ders kitaplarında turistik mekânların isimlerinin belirtilerek haklarında bilgi verildiği ve konuların birçok etkinlik örnekleriyle zenginleştirildiği tespit edilmiştir. Ayrıca UNESCO dünya mirası listesinde yer alan mekânlarla alakalı bilgiler verilerek tanıtımı yapılmıştır. Ülkeler ve turizm potansiyelleri hakkında bilgilere yer verilmiş ve bu ülkelerin dünya haritasındaki konumu da gösterilerek somutlaştırılmıştır. Kitaplarda bu kavram ile ilgili görsellerin turizmin bütün boyutlarını kapsayacak şekilde çeşitlilik arz ettiği tespit edilmiştir. Görsellerin metin ile ilişkilendirilmesi de konunun öğrenciler açısından öğrenmenin daha kalıcı olmasını sağlayacak bir boyut kattığ1 söylenebilir.

Yapılan araştırma sonucunda; Turizm kavramına yer verme durumunun İran sosyal bilgiler yedinci sınıf ders kitabında daha çok olmak üzere iki ders kitabı arasında farklılık olduğu tespit edilmiştir. Bu nedenle farklı kademelerde okutulan ders kitapları arasında turizm kavramına dengeli olarak yer verilmesi, turizmin ekonomik boyutuna daha fazla değinilmesinin uygun olacağı görülmüştür. Ayrıca diğer kademelerdeki sosyal bilgiler ders kitaplarında da turizm kavramıla ilişkili çalışmaların yapılması ve başka ülkelerin sosyal bilgiler programı ve ders kitapları ile ilgili karşılaştırmalı çalışmaların yapılmasının alana katkı sağlayacağı yönünde önerilerde bulunulabilir. 


\title{
EXTENDED ABSTRACT
}

\section{Tourism Concept in Iranian Social Studies Textbooks}

\author{
Kemal Kaya \\ Van Yüzüncü Yıl Üniversitesi
}

Due to its geographical location, Iran is one of the countries where four seasons can be experienced at the same time. It has an advanced tourism potential due to its historical, religious, natural and cultural structure. The tourism potential of Iran has very suitable features in terms of getting its share from the world tourism pie in case of making the necessary investments in tourism resources. In today's world, although the tourism industry is seen as the main and purest industry in terms of revenues, current facts show that the world countries do not generate an income in proportion to their tourism potential. Although Iran ranks 10th in the world in terms of its touristic attractions, it is among the lowest income countries in the world in terms of tourism income.

Today, tourism activities, which are performed professionally, continue to grow and develop. The tourism sector is a resource that creates employment for countries, generates foreign currency and supports economic growth. Due to these features, it has turned into an arena where countries compete with each other. States are making large investments in the tourism sector and trying to increase their tourist attraction by giving importance to promotion. They strive to build the infrastructure of the industry on solid foundations in order to benefit more from the global tourism cake. All these reveal how important tourism education is. Providing the opportunity to have information about the historical and natural beauties of the country, being aware of its economic dimensions, and its contributions in the development of the tourism infrastructure reveal the necessity of tourism education. In order to improve the tourism potential of Iran, which is quite weak compared to other countries and lacks competitive power, suggestions are also made for providing tourism education at higher education level. Because education is seen as the most effective way to teach the concept of tourism and to comprehend its importance for the country. It is possible for individuals to learn what they are expected to acquire through education and to gain awareness in this di- 
rection. Textbooks are one of the important tools of the educational environment designed for this purpose. If the concept of tourism is used in the content of the textbook material in a correct and effective manner, it will be easier for the new generations to gain a more sensitive and conscious perspective towards the sector.

In Iran, textbooks continue to be the most important and almost the only source of the education and training process. The social studies course is taught in the second half of primary school, the fourth, fifth and sixth grades, and at the secondary school level in Iran. With the restructuring process in Turkey's education system in Iran, which corresponds to the same period of the educational reforms made, the process of education-are rearranged according to the constructivism approach. Within the framework of restructuring, primary school was increased to 6 years starting from the 2016-2017 academic year, while high school education was reduced from 4 years to 3 years. Thus, the 12-year education period was arranged as $6+3+3$. Since the 20162017 academic year, the new curriculum has been put into practice and accordingly, newly written social studies textbooks have been started to be taught. In Iran, textbooks are published by the Iranian Ministry of Education and are used as the main source in all schools. When the literature is reviewed, it is seen that there is no study on tourism and its components in the curriculum and textbooks at the secondary school level in Iran. For this reason, considering that one of the ways of teaching tourism, which is of great importance to the Iranian economy, to future generations, is education, it is thought that it is important to focus on this issue. For this purpose, it was deemed necessary to conduct a study on Iranian social studies textbooks, which are one of the important tools in teaching the concept of tourism.

This study aimed to determine the extent to which the phenomenon of tourism is processed and used in social studies textbooks in Iranian secondary schools in the 2018-2019 academic year at the concept, visual and activity level.

Tourism sector, which is one of the important sources of income for the world and Iranian economy, is included in both the general aims of the Iranian social studies course and in the curriculum. The findings obtained as a result of the study show that the concept of tourism is included in Iranian social studies textbooks in a way that differs at the grade level. It can be said that the structure of the social studies program, the type of the topics covered 
by the books and the development levels of the students lead to this differentiation.

There are 172 expressions and 120 visuals about tourism and its components in the social studies textbook of the seventh grade. In the social studies eighth grade textbook, 48 expressions and 29 visuals about tourism and its components were included. When the textbooks of both classes are compared; It has been determined that more expressions and visuals related to the concept of tourism are included in the textbook of the seventh grade compared to the eighth grade textbook of social studies. The reason for this can be considered as the fact that there is a unit called "What is Tourism" in the seventh grade social studies textbook and the subject is handled in detail. Another reason is that while the seventh-grade social studies textbook includes the subjects of Iran's history and geography, the eighth-grade textbook includes topics on world history and geography. It can be stated that the differentiation between the two textbooks in terms of including the concept of tourism is in accordance with the principle of close and far, which is frequently used in education and training processes.

One of the findings of the study shows that the tourism activities in Iran are concentrated in a different type from many parts of the world. Considering visiting holy places as a religious duty in Shia culture continues as a longstanding practice. Numerical data on the mobility that occurs with visiting sacred places within all tourism activities also confirm this.

As a result of the research; It has been determined that the situation of including the concept of tourism is different between the two textbooks, mostly in the Iranian social studies seventh grade textbook. For this reason, it has been seen that it would be appropriate to include the concept of tourism in a balanced manner among the textbooks that are taught at different levels and to touch more on the economic dimension of tourism. In addition, suggestions can be made that conducting studies related to the concept of tourism in social studies textbooks at other levels and making comparative studies on the social studies curriculum and textbooks of other countries will contribute to the field. 


\section{Kaynakça / References}

Algar, H. (2000), İran- kültür ve medeniyet: Dini hayat ve dini kurumlar. İslâm Ansiklopedisi, 22, İstanbul: Türkiye Diyanet Vakfi.

Barth, J. L. ve Demirtaş, A. (1997). İköğretim sosyal bilgiler öğretimi: Kaynak üniteler. Ankara: YÖK/Dünya Bankası Milli Eğitimi Geliştirme Projesi Hizmet Öncesi Öğretmen Eğitimi.

Baum, T. G., ve O'Gorman, K. D. (2010). Iran or Persia: What's in a name, the decline and fall of a tourism industry? Tourism and political change. In R. Butler, \&W. Suntikul (Eds.), Tourism and Political Change, Oxford: Goodfellow Publishers.

Creswell, J. W. (2013). Nitel araştırma yöntemleri. Çev. Ed. M. Bütün, S. Beşir Demir, 3. Bask1, Ankara: Siyasal Kitabevi.

Doğanay, H. (2002). Coğrafya öğretim yöntemleri. Erzurum: Aktif Yayınevi.

Euromonitor International (2017). Travel in Iran: 17 October. 20 Şubat 2018 tarihinde www.portal.euromonitor.com adresinden erişilmiştir.

Habibi F., Rahmati M., ve Karimi, A. (2018). Contribution of tourism to economic growth in Iran's Provinces: GDM approach, Future Business Journal, 4, 261-271.

Fayzipour, M. ve İmami, M.M. (1391). Tawsi'e-i iktisadî san'at-1 gerdişgerî der İran we mukayese-i ân ba kişverhay-1 muntıka-i send çeşmendaz, Mutaleat-lMuduriyet$i$ Gerdisgeri, 7(19), 139-177.

ICHTO (2017). Iranian cultural heritage, handicraft and tourism organization.

İlhan, G. O., Şeker, M., ve Kapıcı, H. Ö., (2015). Sosyal bilgiler beşinci sınıf ders kitaplarinda turizm kavraminin yeri. International Journal of Field Education, 1(1), 42-62.

İsb 7 (2018). Mutaleat-i ictimai (Medeni, Coğrafya, Tarih), Paye-i Heftum, Devre-i Evveli Mutavassite, Tehran.

İsb 8 (2018). Mutaleat-ı İctimai (Medeni, Coğrafya, Tarih), Paye-i Heștum, Devre-i Evveli Mutavassite, Tehran.

Kaya, K. (2019). Yeni sosyal bilgiler programı ve ders kitaplarında turizm kavramı. The Journal of Social Sciences Institue, 43, 173-194.

Kim, W., Jun, H.M., Walker, M., ve Drane, D. (2015). Evaluating the perceived social impacts of hosting large-scale sport tourism events: Scale development and validation. Tourism Management, 48, 21-32.

Kaffashi, M., (2009). The role of education in tourism industry boom and tourist satisfaction in Iran. The Journal of Modern Thoughts in Education, 4(4), Autumn, 141164.

Mehralizadeh Y. (2017). Tourism and Iran's higher education: Interaction or confrontation. Amirkabır, 3(5), 39-52. 
Mehryar, A. H., ve Ahmad-Nia, S. (2004). Age-structural transition in Iran: Short and long termconsequences of drastic fertility swings during the final decades of twentieth century. $\quad$ http://www.cicred.org/Eng/Seminars/Details/Seminars/Popwaves/PopwavesMehryarAhmad-Nia.pdf adresinden erişilmiştir.

Morakabati, Y. (2011). Deterrents to tourism development in Iran. International Journal of Tourism Research, 13(2), 103-23.

Naskali, E. (2000), İran: Başlangıçtan Müslümanlar tarafından fethine kadar. İslâm Ansiklopedisi, 22, İstanbul: Türkiye Diyanet Vakfı.

Patton, M. Q. (2014). Nitel araştırma ve değerlendirme yöntemleri. (M. Bütün, \& S. B. Demir, Çev.) Ankara: Pegema Yayınclik.

Samedian, E, Hoseini, S. H, ve Ava, M. N. R., (1388). Nakş-i amuzeş ber tawsi-i zirsahtha der sana'at-1 turizm-i İran. Fasılname-i İmî pejuheşi coğrafyay-i insani, 4 (1), 103118.

Seyfi, S., ve Hall, C.M. (2019). Tourism in Iran: an introduction. in Tourism in Iran, Eds: Siamak Seyfi and C. Michael Hall, Newyork: Routledge.

Schubert, F. S., Brida, J. G., ve Risso, W. A. (2010). The impacts of international tourism demand on economic growth of small economies dependent of tourism. Tourism Management, 32(2), 377-385.

Sequeira, T. N., \& Nunes, P. M. (2008). Does tourism influence economic growth? A dynamic panel data approach. Applied Economics, 40, 2431-2441.

Shakoori, A. ve Aghdam, S.M.M., (2014). A comparatıve analysis of the impact of liberalization of air transport on tourism: Iran, Turkey and Uae ,Tourismos: An International Multidisciplinary Journal Of Tourism, 9(2), 259-278.

Tang, H. C. H., ve Jang, S. S. C. (2009). The tourism-economy causality in the United States: A sub-industry level examination. Tourism Management, 30, 553-558.

Tavşancıl, E. ve Aslan, E. (2001). Sözel, yazılı ve diğer materyaller için içerik analizi ve uygulama örnekleri. İstanbul: Epsilon Yayıncllik.

UNESCO (2018). World heritage: Iran. 27 Mart 2018 tarihinde

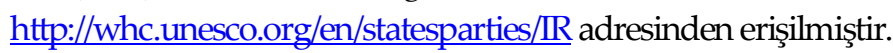

United Nations World Tourism Organization (UNWTO). (2015). Tourism highlight. http://www.e-unwto.org/doi/book/10.18111/9789284416899 adresinden erişilmiştir.

Yıldırım, A. ve Şimşek, H. (2016). Sosyal bilimlerde nitel araştırma yöntemleri. Ankara: Seçkin Yayıncilik. 
Kemal Kaya

Kaynakça Bilgisi / Citation Information

Kaya, K. (2021). İran Sosyal Bilgiler ders kitaplarında turizm kavramı. OPUS-Uluslararası Toplum Araştırmaları Dergisi, 17(36), 3015-3042. DOI: 10.26466/opus.714104 